\title{
Эндо- и эпифитные бактерии картофеля дикого типа - продуценты экспериментальных образцов микробных препаратов для биологической защиты новых сортов картофеля
}

\author{
В.К. Чеботарь*, А.В. Щербаков, Е.Н. Щербакова, Л.М. Яхина, О.В. Комарова, \\ Ю.В. Лактионов, А.П. Кожемяков, И.А. Тихонович \\ Всероссийский научно-исследовательский институт сельскохозяйственной микробиологии РАН, \\ Санкт-Петербург, Россия \\ *e-mail:vladchebotar@rambler.ru
}

Для селекции картофеля актуальным является использование эффективных и экологически безопасных микробных препаратов, повышающих продуктивность и устойчивость растений к неблагоприятным факторам среды и болезням. Спомощью разработанных методик из клубней картофеля дикого типа выделено 65, а из клубней культурного вида - 50 изолятов эндофитных и эпифитных бактерий. Проведено сравнение микробиомов штаммов микроорганизмов, выделенных из сортов дикого и культурного вида растений картофеля, и обнаружено, что в составе микробиома дикого вида преобладают бактериальные штаммы - 77 \%, численность актинобактерий составляла $18 \%$, грибов - 4,6 \%, в то время как в составе микробиома культурного вида среди изолятов обнаружено 62 \% бактерий, $32 \%$ актиномицетов и 6 \% грибов. Наибольшее число микроорганизмов, способных стимулировать рост растений и подавлять фитопатогенные грибы, выделено из клубней дикого вида.

Выделенные изоляты проанализированы на способность к продукции ИУК, ростостимуляции, фунгицидной активности, продукции разных ферментов и способности расти при пониженных температурах.

В результате анализа свойств выделенных бактериальных штаммов отобрано 10 изолятов для идентификации с помощью анализа нуклеотидной последовательности гена $16 \mathrm{~S}$ рРНК. Установлена родовая и видовая принадлежность выбранных изолятов.

С целью создания биопрепаратов, имеющих антистрессовое и защитное действие для растений картофеля, отобрано три штамма с требуемыми свойствами и два штамма для применения при хранении сельскохозяйственной продукции в условиях промышленных картофелехранилищ. Оптимизированы составы питательных сред и отработаны технологические параметры культивирования семи штаммов микроорганизмов, разработаны проекты технологических регламентов получения семи экспериментальных образцов микробных препаратов.

Благодарности: Работа выполнена при финансовой поддержке проекта «Развитие селекции и семеноводства картофеля в Российской Федерации» Федеральной научно-технической программы развития сельского хозяйства на 2017-2025 гг. 